\title{
Major nutrient contents and their uptake by brinjal as influenced by phosphorus and sulphur
}

\author{
M. M. Hasan*, M. A. H. Chowdhury, B. K. Saha and M. R. Islam \\ Department of Agricultural Chemistry, Bangladesh Agricultural University, Mymensingh-2202, Bangladesh \\ *E-mail : mehedi.bau236@gmail.com
}

\begin{abstract}
A pot experiment was conducted in the net house of the Department of Agricultural Chemistry, Bangladesh Agricultural University, Mymensingh to evaluate the influence of phosphorus $(P)$ and sulphur (S) on major nutrient contents and their uptake by brinjal (cv. BARI brinjal-8) during the period from October, 2011 to May, 2012. The experiment was laid out in a completely randomized design with 12 treatments and 3 replications using four levels of $P\left(0,30,60\right.$ and $\left.90 \mathrm{~kg} \mathrm{P} \mathrm{ha}^{-1}\right)$ and three levels of $S\left(0,15\right.$ and $\left.30 \mathrm{~kg} \mathrm{~S} \mathrm{ha}^{-1}\right)$ along with the basal doses of urea, muriate of potash, boric acid, zinc oxide, cowdung and poultry manure. The study revealed that major nutrient contents and their uptake were significantly influenced by $\mathrm{P}$ and $\mathrm{S}$ interactions. They had positive significant effects on major nutrient contents and their uptake. Application of $\mathrm{P}$ increased $\mathrm{N}, \mathrm{P}, \mathrm{K}, \mathrm{Ca}, \mathrm{Mg}$ and $\mathrm{S}$ contents and their uptake upto $60 \mathrm{~kg} \mathrm{ha}^{-1}$ and over the dose the values were reduced or near to control treatment. Similarly, the gradual increases of major nutrient contents and their uptake were found in $\mathrm{S}$ application upto $30 \mathrm{~kg} \mathrm{ha}^{-1}$. Among the treatments the combination of P @ $60 \mathrm{~kg} \mathrm{ha}^{-1}$ and S@ $30 \mathrm{~kg} \mathrm{ha}^{-1}$ showed the highest $\mathrm{N}, \mathrm{P}, \mathrm{K}, \mathrm{S}, \mathrm{Ca}$ and $\mathrm{Mg}$ contents and their uptake. The lowest values were found in control treatment. Results showed that an appropriate interaction of $\mathrm{P}$ and $\mathrm{S}$ increased major nutrient contents of brinjal.
\end{abstract}

Keywords: Phosphorus, Sulphur, Brinjal, Interaction, Major nutrient contents and their uptake

\section{Introduction}

Fertilizers supply one or more essential plant nutrients which are essential for the growth, yield and quality of crops. Among the essential plant nutrients $\mathrm{P}$ and $\mathrm{S}$ play a vital role on nutrient contents and uptakes of vegetable crops. As a popular and widely grown vegetable crop, brinjal (Solanum melongena L.) is grown extensively round the year in Bangladesh and ranks third in terms of consumption. Fruits of brinjal contain $92.7 \%$ water, $1.4 \%$ protein, $0.3 \%$ fat, $1.3 \%$ fibre and $4.0 \%$ carbohydrate, appreciable amount of $\mathrm{Ca}, \mathrm{Mg}$, $\mathrm{P}, \mathrm{S}, \mathrm{K}, \mathrm{Na}, \mathrm{Fe}$, source of vitamin A and B but poor in vitamin C (Bose and Som, 1986). Generally, solanaceous vegetables require large quantities of major nutrients like $\mathrm{N}, \mathrm{P}$ and $\mathrm{K}$. In addition, some secondary nutrients such as $\mathrm{Ca}$ and $\mathrm{S}$ are largely required for better growth, fruit and seed yield. Among the plant nutrients $\mathrm{P}$ and $\mathrm{S}$ have a great influence on the nutrient contents and uptake by brinjal.

The most obvious effect of $P$ is on the plant root system; it promotes root formation and the formation of lateral fibrous and healthy roots (Parihar and Tripathi, 2003). It was obtained that $P$ is required for the formation of phosphides, nucleoproteins, nucleic acids, adenosine diphosphates, carbohydrates synthesis and nutrient contents like $\mathrm{Ca}, \mathrm{Mg}, \mathrm{N}, \mathrm{K}$ and S (Badiger et al., 2006). As an essential plant nutrient, S improves the yield and quality parameters of important vegetable crops. $S$ is a constituent of secondary compounds viz., allin, cycloallin and thiopropanol which not only influence the taste, pungency and medicinal properties of vegetable crops but also induce resistance against pests and diseases (Tabatabai, 2001). But single and imbalanced application of $P$ and $S$ as fertilizers increases production cost and hampers the fruit quality of brinjal. As a result, a positive interaction is required between $\mathrm{P}$ and $\mathrm{S}$ for the better fruit quality of brinjal. To consider this matter, an experiment was conducted by interacting different levels of $\mathrm{P}$ and $\mathrm{S}$ to evaluate the effect of $\mathrm{P}$ and $\mathrm{S}$ on major nutrient contents and their uptake by brinjal.

\section{Materials and Methods}

The pot experiment was carried out in the net house of the Department of Agricultural Chemistry, Bangladesh Agricultural University, Mymensingh during the period from October, 2011 to May, 2012. Soil sample was collected from Genetics and Plant Breeding field laboratory after harvesting of crop at fallow condition. The soil was silt loam in texture having $\mathrm{pH} 6.08$ with $0.71 \% \mathrm{OC}, 0.10 \% \mathrm{~N}, 12.60 \mu \mathrm{g} \mathrm{g}^{-1}$ available $\mathrm{P}, 10.90 \mu \mathrm{g} \mathrm{g}^{-1}$ available $\mathrm{S}$ and $0.14 \mathrm{cmol} \mathrm{kg}^{-1}$ exchangeable $\mathrm{K}$. As a test vegetable crop, seeds of brinjal cv. BARI brinjal-8 were collected from BARI, Gazipur. There were 12 treatment combinations with four levels of $P\left(0,30,60\right.$ and $\left.90 \mathrm{~kg} \mathrm{P} \mathrm{ha}^{-1}\right)$ and three levels of $S\left(0,15\right.$ and $\left.30 \mathrm{~kg} \mathrm{Sha}^{-1}\right)$. The experiment was laid out in completely randomized design with three replications. Recommended doses of urea, MoP, boric acid, zinc oxide, cowdung and poultry manure were mixed thoroughly with soil according to the 
fertilizer recommendation guide (BARC, 1997). Cowdung and poultry manure were mixed with soils 7 days before pot preparation and the other recommended fertilizers were given to the soil before transplanting the brinjal seedling. Urea was applied in 3 split applications. The pots were filled with $10 \mathrm{~kg}$ soil. Seeds were sown in separate pot and then, seedlings were transplanted when they were 30 days age. All necessary intercultural operations were performed as and when necessary throughout the growing period of brinjal. Irrigation was given everyday upto 45 DAT and then every alternate day upto the harvest. The brinal fruits were collected in the laboratory and $\mathrm{N}, \mathrm{P}, \mathrm{K}, \mathrm{S}, \mathrm{Ca}$ and $\mathrm{Mg}$ contents of brinjal fruits were determined by semi-micro kjeldahl method (Jackson, 1973 and Page et al., 1982), spectrophotometric method (Page et al., 1982), flame emission spectrophotometric method (Ghosh et al., 1983), complexometric method of titration using $\mathrm{Na}_{2}$-EDTA (Page et al., 1982) and turbidimetrically (Tandon, 1995) respectively. The nutrients uptake by brinjal were calculated by using yield data that was represented by Hasan et al. (2013). Analysis of variance was done with the help of computer package program MSTAT-C according to Gomez and Gomez (1984) and the mean differences among different treatments were adjudged by DMRT test at $5 \%$ level of probability.

\section{Results and Discussion}

\section{Nutrient contents in brinjal}

Nitrogen content: Phosphorus had significant effect on $\mathrm{N}$ content of brinjal. The highest content $1.10 \%$ was observed from the treatment of $60 \mathrm{~kg} \mathrm{P} \mathrm{ha}^{-1}$ (Table 1) and the lowest content $(0.79 \%)$ was found in the control treatment. The above findings were similar to those of Dass and Mishra (2002) who reported that $\mathrm{N}$ content in fruit was increased with the increasing rate of $\mathrm{P}$ application and $\mathrm{P} @ 60 \mathrm{~kg} \mathrm{ha}^{-1}$ produced maximum $\mathrm{N}$ content in chilli. The content of $\mathrm{N}$ in brinjal fruits was statistically influenced due to $\mathrm{S}$ application. The maximum content $(0.97 \%)$ was observed from treatment of $30 \mathrm{~kg} \mathrm{~S} \mathrm{ha}^{-1}$ (Table 2) and the minimum content $(0.86 \%)$ was found in the control treatment. The above findings are similar to those of Sivakumaran (2005) who reported that $\mathrm{S}$ application increased $\mathrm{N}$ content in coriander fruit. It appears from the results due to the application of increased level of $S$ up to $40 \mathrm{~kg} \mathrm{ha}^{-1}$. This result might be due to a synergistic effect between $\mathrm{S}$ and $\mathrm{N}$. The interaction effects of $\mathrm{P}$ and $\mathrm{S}$ on $\mathrm{N}$ content was statistically significant. The highest content (1.27\%) was observed from the treatment of $\mathrm{P}_{60} \mathrm{~S}_{30}$ and the lowest content $(0.62 \%)$ was found in the control treatment (Table 3$)$. This finding was similar to those of Hariyappa (2006) and reported that $\mathrm{N}$ content increased in $\mathrm{P}_{60} \mathrm{~S}_{30}$ level in onion.

Phosphorus content: The experimental results showed that $\mathrm{P}$ content of brinjal was statistically affected by the application of $P$. The maximum content $(0.53 \%)$ was observed from $60 \mathrm{~kg} \mathrm{P}^{-1}$ and the lowest content $(0.39 \%)$ was found in control (Table 1$)$. The above findings were similar to those of Balasubramanian et al. (2005) who reported that P content increased significantly with P application but above $70 \mathrm{~kg} \mathrm{P}^{-1}$ application, $\mathrm{P}$ content was reduced. The content of $\mathrm{P}$ in brinjal fruit was significantly influenced by $S$. The highest $P$ content $(0.51 \%)$ was found from $30 \mathrm{~kg} \mathrm{~S}^{-1}$ and the lowest content $(0.44 \%)$ was observed from control (Table 2). The above findings were similar to those of Sivakumaran (2005) and reported that $P$ content in coriander increased with increased level of applied S. The interaction effects of $P$ and $S$ on $P$ content was significant. The highest $P$ content $(0.67 \%)$ was found from $\mathrm{P}_{60} \times \mathrm{S}_{30} \mathrm{~kg} \mathrm{ha}^{-1}$ and the lowest content (0.34\%) was observed from control (Table 3). It was occurred due to the synergistic effect of the combination of $P$ and $S$ and availability of $P$ in soil.

Potassium content: Application of $\mathrm{P}$ had significant effect on $\mathrm{K}$ content of brinjal fruit. The highest content $(0.46 \%)$ was found from $60 \mathrm{~kg} \mathrm{P} \mathrm{ha}^{-1}$ and the lowest content $(0.22 \%)$ was recorded from control (Table 1). The above findings were similar to those of Kadu el al. (2005) and reported that K percentage in grain of rice was the highest with N, P and K application. Sulphur fertilization had significant effect on K content of brinjal fruit. The maximum K content (0.38\%) was found from the treatment of $30 \mathrm{~kg} \mathrm{~S} \mathrm{ha}^{-1}$ and the minimum $(0.28 \%)$ content was observed from control (Table 2$)$. The above findings were similar to those of Satter and Ahmed (2008), who reported that K content in wheat grain was increased significantly with the application of 30 to $45 \mathrm{~kg} \mathrm{~S} \mathrm{ha}^{-1}$. The interaction effects of $\mathrm{P}$ and $\mathrm{S}$ on $\mathrm{K}$ content was also significant. The maximum content $(0.59 \%)$ was observed from the treatment of $P_{60} \times S_{30} \mathrm{~kg} \mathrm{ha}^{-1}$ and the minimum from control (Table 3). It might be occurred due to the synergistic effect of the combination of $P$ and $\mathrm{S}$ that influenced the $\mathrm{K}$ content in brinjal. 
Table 1. Effect of $P$ on fruit nutrient contents and their uptake by brinjal cv. BARI brinjal-8

\begin{tabular}{|c|c|c|c|c|c|c|c|c|c|c|c|c|}
\hline \multirow[t]{2}{*}{ Treatments } & \multicolumn{2}{|c|}{ Nitrogen } & \multicolumn{2}{|c|}{ Phosphorus } & \multicolumn{2}{|c|}{ Potassium } & \multicolumn{2}{|c|}{ Sulphur } & \multicolumn{2}{|c|}{ Calcium } & \multicolumn{2}{|c|}{ Magnesium } \\
\hline & $\begin{array}{c}\text { Content } \\
(\%)\end{array}$ & $\begin{array}{c}\text { Uptake } \\
\left(\mathrm{mg} \mathrm{pot}^{-1}\right)\end{array}$ & $\begin{array}{c}\text { Content } \\
(\%)\end{array}$ & $\begin{array}{c}\text { Uptake } \\
\left(\mathrm{mg} \mathrm{pot}^{-1}\right)\end{array}$ & $\begin{array}{c}\text { Content } \\
(\%)\end{array}$ & $\begin{array}{c}\text { Uptake } \\
\left(\mathrm{mg} \mathrm{pot}^{-1}\right)\end{array}$ & $\begin{array}{c}\text { Content } \\
(\%)\end{array}$ & $\begin{array}{c}\text { Uptake } \\
\left(\mathrm{mg} \mathrm{pot}^{-1}\right)\end{array}$ & $\begin{array}{c}\text { Content } \\
(\%)\end{array}$ & $\begin{array}{c}\text { Uptake } \\
\left(\mathrm{mg} \mathrm{pot}^{-1}\right)\end{array}$ & $\begin{array}{c}\text { Content } \\
(\%)\end{array}$ & $\begin{array}{c}\text { Uptake } \\
\left(\mathrm{mg} \mathrm{pot}^{-1}\right)\end{array}$ \\
\hline $\mathrm{P}_{0}$ & $0.79 \mathrm{c}$ & $385 c$ & $0.39 \mathrm{~b}$ & $187 \mathrm{~b}$ & $0.22 \mathrm{c}$ & $112 \mathrm{c}$ & $0.10 \mathrm{~d}$ & $52 \mathrm{C}$ & $0.39 c$ & $192 c$ & $0.28 d$ & $138 \mathrm{c}$ \\
\hline$P_{30}$ & $0.96 a b$ & $458 b$ & $0.50 \mathrm{a}$ & $309 a$ & $0.34 b$ & $211 b$ & $0.18 \mathrm{c}$ & $112 b$ & $0.50 \mathrm{~b}$ & $309 b$ & $0.36 c$ & $224 b$ \\
\hline$P_{60}$ & $1.10 \mathrm{a}$ & $659 a$ & $0.53 a$ & $372 a$ & $0.46 a$ & $317 a$ & $0.34 a$ & $234 a$ & $0.61 a$ & $419 a$ & $0.51 a$ & $354 a$ \\
\hline$P_{90}$ & $0.84 b c$ & $397 \mathrm{bc}$ & $0.49 a$ & $221 b$ & $0.29 b c$ & $130 \mathrm{c}$ & $0.24 b$ & $109 \mathrm{~b}$ & $0.52 b$ & $239 b c$ & $0.42 b$ & $190 \mathrm{bc}$ \\
\hline SE \pm & 0.094 & 0.042 & 0.047 & 0.021 & 0.055 & 0.021 & 0.050 & 0.017 & 0.045 & 0.021 & 0.049 & 0.020 \\
\hline CV (\%) & 8.04 & 11.41 & 6.87 & 17.99 & 9.27 & 19.02 & 6.87 & 25.38 & 6.05 & 11.21 & 8.92 & 11.11 \\
\hline
\end{tabular}

N.B.: Means following by the same letter in a column are not significantly different at $5 \%$ level by DMRT.

$\mathrm{CV}=$ Coefficient of variation

Sulphur content: Phosphorus had significant effect on $\mathrm{S}$ content of brinjal fruit. The highest content (0.34\%) was observed from $60 \mathrm{~kg} \mathrm{P}^{-1}$ and the lowest content $(0.10 \%)$ was found from control (Table 1$)$. Nanadal et al. (2008) tried four levels of $P$ such as $0,30,60$ and $120 \mathrm{~kg} \mathrm{P}^{-1}$ in tomato and reported that the superior amount of $S$ was obtained with application of $60 \mathrm{~kg} \mathrm{ha}^{-1}$. Application of $S$ had a significant effect on S content of brinjal fruit. The maximum S content $(0.25 \%)$ was found from the treatment of $30 \mathrm{~kg}$ $\mathrm{S} \mathrm{ha}^{-1}$ and the minimum $(0.18 \%)$ content was observed from control (Table 2). Thakre et al. (2005) observed that the increased levels of $\mathrm{S}$ significantly increased the ash, ascorbic acid, $\mathrm{S}$ and protein contents in brinjal fruit. The values of these parameters were maximum with the application of $40 \mathrm{~kg} \mathrm{~S} \mathrm{ha}^{-1}$ in the form of gypsum. The content of $S$ in brinjal fruit was significantly influenced by the interaction effect of $P$ and $S$. The highest content $(0.44 \%)$ was observed from the treatment of $P_{60} \times S_{30} \mathrm{~kg}^{-1}$ and the lowest from control (Table 3).

Table 2. Effect of S on fruit nutrient contents and their uptake by brinjal cv. BARI brinjal-8

\begin{tabular}{|c|c|c|c|c|c|c|c|c|c|c|c|c|}
\hline \multirow[t]{2}{*}{ Treatments } & \multicolumn{2}{|c|}{ Nitrogen } & \multicolumn{2}{|c|}{ Phosphorus } & \multicolumn{2}{|c|}{ Potassium } & \multicolumn{2}{|c|}{ Sulphur } & \multicolumn{2}{|c|}{ Calcium } & \multicolumn{2}{|c|}{ Magnesium } \\
\hline & $\begin{array}{c}\text { Content } \\
(\%)\end{array}$ & $\begin{array}{l}\text { Uptake } \\
\left(\mathrm{mg} \mathrm{pot}^{-1}\right)\end{array}$ & $\begin{array}{c}\text { Content } \\
(\%)\end{array}$ & $\begin{array}{c}\text { Uptake } \\
\left(\mathrm{mg} \mathrm{pot}^{-1}\right)\end{array}$ & $\begin{array}{c}\text { Content } \\
(\%)\end{array}$ & $\begin{array}{l}\text { Uptake } \\
\left(\mathrm{mg} \mathrm{pot}^{-1}\right)\end{array}$ & $\begin{array}{c}\text { Content } \\
(\%)\end{array}$ & $\begin{array}{c}\text { Uptake } \\
\left(\mathrm{mg} \mathrm{pot}^{-1}\right)\end{array}$ & $\begin{array}{c}\text { Content } \\
(\%)\end{array}$ & $\begin{array}{c}\text { Uptake } \\
\left(\mathrm{mg} \mathrm{pot}^{-1}\right)\end{array}$ & $\begin{array}{c}\text { Content } \\
(\%)\end{array}$ & $\begin{array}{c}\text { Uptake } \\
\left(\mathrm{mg} \mathrm{pot}^{-1}\right)\end{array}$ \\
\hline $\mathrm{S}_{0}$ & $0.86 \mathrm{~b}$ & $416 b$ & $0.44 b$ & $213 b$ & $0.28 \mathrm{~b}$ & $138 \mathrm{~b}$ & $0.18 \mathrm{c}$ & $91 b$ & $0.48 \mathrm{~b}$ & $231 b$ & $0.37 \mathrm{~b}$ & $182 b$ \\
\hline $\mathrm{S}_{15}$ & $0.92 \mathrm{ab}$ & $556 a b$ & $0.48 a b$ & $283 a b$ & $0.32 \mathrm{ab}$ & $190 a b$ & $0.21 b$ & $127 \mathrm{~b}$ & $0.50 \mathrm{a}$ & $301 a b$ & $0.39 a b$ & $234 a b$ \\
\hline $\mathrm{S}_{30}$ & $0.97 a$ & $625 a$ & $0.51 \mathrm{a}$ & $322 a$ & $0.38 a$ & $250 a$ & $0.25 a$ & $161 a$ & $0.53 a$ & $335 a$ & $0.42 a$ & $263 a$ \\
\hline SE \pm & 0.109 & 0.048 & 0.054 & 0.025 & 0.063 & 0.024 & 0.058 & 0.019 & 0.052 & 0.025 & 0.057 & 0.023 \\
\hline CV (\%) & 8.04 & 11.41 & 6.87 & 17.99 & 9.27 & 19.02 & 6.87 & 25.38 & 6.05 & 11.21 & 8.92 & 11.11 \\
\hline
\end{tabular}

N.B.: Means following by the same letter in a column are not significantly different at $5 \%$ level by DMRT.

$\mathrm{CV}=$ Coefficient of variation

Table 3. Interaction effects of $P$ and $S$ on fruit nutrient contents and their uptake by brinjal cv. BARI brinjal-8

\begin{tabular}{|c|c|c|c|c|c|c|c|c|c|c|c|c|}
\hline \multirow[t]{2}{*}{ Treatments } & \multicolumn{2}{|c|}{ Nitrogen } & \multicolumn{2}{|c|}{ Phosphorus } & \multicolumn{2}{|c|}{ Potassium } & \multicolumn{2}{|c|}{ Sulphur } & \multicolumn{2}{|c|}{ Calcium } & \multicolumn{2}{|c|}{ Magnesium } \\
\hline & $\begin{array}{c}\text { Content } \\
(\%)\end{array}$ & $\begin{array}{c}\text { Uptake } \\
\text { (mg pot-1) }\end{array}$ & $\begin{array}{c}\text { Content } \\
(\%)\end{array}$ & $\begin{array}{c}\text { Uptake } \\
\left(\text { mg pot }^{-1}\right)\end{array}$ & $\begin{array}{c}\text { Content } \\
(\%)\end{array}$ & $\begin{array}{c}\text { Uptake } \\
\text { (mg pot-1) }\end{array}$ & $\begin{array}{c}\text { Content } \\
(\%)\end{array}$ & $\begin{array}{c}\text { Uptake } \\
\left(\mathrm{mg} \mathrm{pot}^{-1}\right)\end{array}$ & $\begin{array}{c}\text { Content } \\
(\%)\end{array}$ & $\begin{array}{c}\text { Uptake } \\
\text { (mg pot-1) }^{-1}\end{array}$ & $\begin{array}{c}\text { Content } \\
\text { (\%) }\end{array}$ & $\begin{array}{c}\text { Uptake } \\
\text { (mg pot-1) }\end{array}$ \\
\hline $\mathrm{P}_{0} \mathrm{~S}_{0}$ & $0.62 \mathrm{~g}$ & $213 e$ & $0.34 \mathrm{e}$ & $117 d$ & $0.12 f$ & $39 f$ & $0.06 \mathrm{~g}$ & $21 \mathrm{e}$ & $0.31 \mathrm{e}$ & $107 \mathrm{~g}$ & $0.21 f$ & $70 \mathrm{~g}$ \\
\hline $\mathrm{P}_{0} \mathrm{~S}_{15}$ & 0.85 def & 463cd & $0.40 \mathrm{de}$ & $218 c$ & $0.27 \mathrm{e}$ & 146de & $0.12 f$ & 65de & $0.43 d$ & 234def & $0.32 \mathrm{e}$ & 174ef \\
\hline $\mathrm{P}_{0} \mathrm{~S}_{30}$ & 0.90 cde & 491cd & $0.42 \mathrm{cde}$ & $229 c$ & $0.28 \mathrm{e}$ & 151de & $0.13 f$ & 70de & $0.44 d$ & 237def & $0.31 \mathrm{e}$ & $169 \mathrm{ef}$ \\
\hline $\mathrm{P}_{30} \mathrm{~S}_{0}$ & $0.77 \mathrm{efg}$ & 439cd & $0.49 \mathrm{bc}$ & $276 b c$ & 0.32 cde & 179de & $0.17 \mathrm{ef}$ & $96 \mathrm{~cd}$ & $0.48 \mathrm{~cd}$ & 270de & $0.36 \mathrm{de}$ & 203de \\
\hline $\mathrm{P}_{30} \mathrm{~S}_{15}$ & $1.09 \mathrm{~b}$ & $658 b$ & $0.55 b$ & $330 \mathrm{~b}$ & $0.34 \mathrm{bcd}$ & $205 c d$ & 0.19 de & $114 \mathrm{~cd}$ & $0.50 \mathrm{c}$ & $304 \mathrm{~cd}$ & $0.35 \mathrm{de}$ & 211cde \\
\hline $\mathrm{P}_{30} \mathrm{~S}_{30}$ & $1.01 \mathrm{bc}$ & $702 b$ & $0.47 \mathrm{bc}$ & $325 b$ & $0.36 \mathrm{bc}$ & $250 \mathrm{bc}$ & 0.18de & $112 \mathrm{~cd}$ & $0.51 b c$ & $354 c$ & $0.37 \mathrm{de}$ & $255 c$ \\
\hline $\mathrm{P}_{60} \mathrm{~S}_{0}$ & $1.05 b$ & $541 \mathrm{c}$ & $0.45 b c d$ & $231 \mathrm{c}$ & $0.39 \mathrm{~b}$ & $258 \mathrm{~cd}$ & $0.27 b c$ & $138 \mathrm{c}$ & $0.57 \mathrm{~b}$ & 291de & $0.46 \mathrm{bc}$ & $237 \mathrm{~cd}$ \\
\hline $\mathrm{P}_{60} \mathrm{~S}_{15}$ & $0.98 \mathrm{bcd}$ & $707 \mathrm{~b}$ & $0.47 \mathrm{bc}$ & $338 \mathrm{~b}$ & $0.38 \mathrm{~b}$ & $270 b$ & $0.29 b$ & $208 b$ & $0.57 \mathrm{~b}$ & $411 b$ & $0.48 \mathrm{~b}$ & $346 b$ \\
\hline $\mathrm{P}_{60} \mathrm{~S}_{30}$ & $1.27 \mathrm{a}$ & $1030 a$ & $0.67 a$ & $543 a$ & $0.59 a$ & $478 a$ & $0.44 a$ & $356 a$ & $0.68 a$ & $551 a$ & $0.59 a$ & $478 a$ \\
\hline $\mathrm{P}_{90} \mathrm{~S}_{0}$ & $1.01 \mathrm{bc}$ & $476 \mathrm{~cd}$ & $0.49 b c$ & $231 \mathrm{c}$ & $0.28 \mathrm{e}$ & $130 \mathrm{e}$ & $0.23 \mathrm{~cd}$ & $117 \mathrm{~cd}$ & $0.54 \mathrm{bc}$ & 255ef & $0.46 \mathrm{bc}$ & 216cde \\
\hline $\mathrm{P}_{90} \mathrm{~S}_{15}$ & $0.78 \mathrm{efg}$ & $395 d$ & $0.49 \mathrm{bc}$ & $247 b c$ & $0.28 \mathrm{e}$ & 140de & $0.25 b c$ & $125 \mathrm{~cd}$ & $0.51 b c$ & 257ef & $0.41 \mathrm{~cd}$ & 205de \\
\hline $\mathrm{P}_{90} \mathrm{~S}_{30}$ & $0.72 \mathrm{fg}$ & $283 e$ & $0.48 \mathrm{bc}$ & $187 \mathrm{~cd}$ & $0.30 \mathrm{de}$ & $117 \mathrm{e}$ & $0.25 b c$ & 96cd & $0.52 \mathrm{bc}$ & $203 f$ & $0.39 d$ & $148 f$ \\
\hline SE \pm & 0.054 & 0.024 & 0.027 & 0.012 & 0.032 & 0.012 & 0.029 & 0.010 & 0.026 & 0.012 & 0.028 & 0.011 \\
\hline CV (\%) & 8.04 & 11.41 & 6.87 & 17.99 & 9.27 & 19.02 & 6.87 & 25.38 & 6.05 & 11.21 & 8.92 & 11.11 \\
\hline
\end{tabular}

N.B.: Means following by the same letter in a column are not significantly different at $5 \%$ level by DMRT.

$\mathrm{CV}=$ Coefficient of variation

Calcium content: All the treatments of $P$ had significant effect on Ca content of brinjal fruit. The highest content $(0.61 \%)$ was found from $60 \mathrm{~kg} \mathrm{P} \mathrm{ha}^{-1}$ and the lowest content $(0.39 \%)$ was observed from control (Table 1). Rachappa (2004) found higher Ca content in carrot with the application of P@60 kg ha $\mathrm{k}^{-1}$ application. The content of $\mathrm{Ca}$ in brinjal fruit was significantly influenced by $\mathrm{S}$ fertilization. The maximum 
Ca content $(0.53 \%)$ was found from the treatment of $30 \mathrm{~kg} \mathrm{~S} \mathrm{ha}^{-1}$ and the minimum $(0.48 \%)$ content was observed from control (Table 2). It was similar to the result of Singh et al. (2007) who concluded that application of $30 \mathrm{~kg} \mathrm{~S} \mathrm{ha}^{-1}$ as gypsum recorded significantly higher $\mathrm{Ca}$ content in potato. The interaction effects of $\mathrm{P}$ and $\mathrm{S}$ on $\mathrm{Ca}$ content was significant. The highest content $(0.68 \%)$ was observed from the treatment of $\mathrm{P}_{60} \times \mathrm{S}_{30} \mathrm{~kg} \mathrm{ha}^{-1}$ and the lowest from control (Table 3). It might be due to the synergistic effect of the combination of $\mathrm{P}$ and $\mathrm{S}$ with $\mathrm{Ca}$.

Magnesium content: Phosphorus had significant effect on $\mathrm{Mg}$ content of brinjal fruit. The highest content $(0.51 \%)$ was recorded from $60 \mathrm{~kg} \mathrm{P} \mathrm{ha}^{-1}$ and the lowest content $(0.28 \%)$ was found from control (Table 1$)$. Similar type of result was reported by Ananthi et al. (2004) in chilli. The effect of S on Mg content of brinjal fruit was statistically significant. The maximum $\mathrm{Mg}$ content $(0.42 \%)$ was found from the treatment of $30 \mathrm{~kg}$ $\mathrm{S} \mathrm{ha}^{-1}$ and the minimum (0.37\%) content was observed from control (Table 2). Gangadhar (2009) noticed that significantly higher essential Mg content and yield were found in the treatment receiving $30 \mathrm{~kg} \mathrm{~S} \mathrm{ha}^{-1}$ fertilizer levels over control in cauliflower. $\mathrm{Mg}$ content of brinjal fruit was significantly influenced by the interaction of $P$ and $S$ fertilizer. The highest $M g$ content $(0.59 \%)$ was found from $P_{60} \times S_{30} \mathrm{~kg} \mathrm{ha}^{-1}$ and the lowest content $(0.21 \%)$ was observed from control (Table 3$)$. It might be occurred due to the synergistic effect of the combination of $\mathrm{P}$ and $\mathrm{S}$ on $\mathrm{Mg}$.

\section{Nutrient uptake by brinjal}

Nitrogen uptake: Significant differences in the uptake of $\mathrm{N}$ were obtained due to various $\mathrm{P}$ levels. $\mathrm{A}$ significantly higher $N$ uptake was recorded in $P_{60}$ level $\left(659 \mathrm{mg} \mathrm{pot}^{-1}\right)$ over $\mathrm{P}_{30}\left(458 \mathrm{mg} \mathrm{pot}^{-1}\right), \mathrm{P}_{90}(397 \mathrm{mg}$ pot $^{-1}$ ) and control (385 mg pot $\left.{ }^{-1}\right)$. The concentration of $N$ in fruit portion of vegetable crops was significantly influenced by the application of different levels of $P$. This result was similar to the result of Dass and Mishra (2002) that application of $P @ 60 \mathrm{~kg} \mathrm{ha}^{-1}$ produced maximum N uptake by chilli fruit. Different levels of $S$ significantly influenced the $N$ uptake. The highest $N$ uptake of $625 \mathrm{mg} \mathrm{pot}^{-1}$ was obtained in $\mathrm{S}_{30}$ level $\left(30 \mathrm{~kg} \mathrm{Sh}^{-1}\right.$ ), which was significantly higher than other treatments and the lowest $\mathrm{N}$ uptake (416 mg pot ${ }^{-1}$ ) was observed in control. A significantly higher concentration of $N$ in fruit portion was recorded at $30 \mathrm{~kg} \mathrm{~S} \mathrm{ha}^{-1}$. This might be due to synergistic effect of S on N. Sivakumaran (2005) reported that $\mathrm{S}$ application significantly influenced the uptake of $\mathrm{N}$. The maximum uptake of $\mathrm{N}$ was recorded at $\mathrm{S}_{30}$ level in crops. The interaction effects of $P$ and $S$ levels were significant. The maximum and minimum nitrogen uptakes were recorded in $\mathrm{P}_{60} \mathrm{~S}_{30}\left(1030 \mathrm{mg} \mathrm{pot}^{-1}\right)$ and $\mathrm{P}_{0} \mathrm{~S}_{0}\left(213 \mathrm{mg} \mathrm{pot}^{-1}\right)$, respectively. Similar result was reported by Singh and Rathore (2004) in linseed crop.

Phosphorus uptake: Application of $\mathrm{P}$ significantly increased the $\mathrm{P}$ uptake of brinjal. The treatment $\mathrm{P}_{60}$ level $\left(60 \mathrm{~kg} \mathrm{Pha}^{-1}\right)$ recorded significantly higher uptake of $\mathrm{P}\left(372 \mathrm{mg} \mathrm{pot}^{-1}\right)$, which was significantly higher than other treatments viz., $P_{30}\left(309 \mathrm{mg} \mathrm{pot}^{-1}\right), P_{90}\left(221 \mathrm{mg} \mathrm{pot}^{-1}\right)$ and $\mathrm{P}_{0}\left(187 \mathrm{mg} \mathrm{pot}^{-1}\right)$. Application of $P$ fertilizer increased particularly $\mathrm{P}$ content in fruit portion. This might be due to higher availability and uptake of $P$ by the crop. Similar observations were made by Balasubramanian et al. (2005) in mustard crop. The application of different levels of $S$ significantly influenced $P$ uptake. Treatment $S_{30}$ recorded significantly the higher uptake of $P\left(322 \mathrm{mg} \mathrm{pot}^{-1}\right)$ compared to other treatments $\left(\mathrm{S}_{15}=283 \mathrm{mg} \mathrm{pot}^{-1}\right.$ and $\mathrm{S}_{0}=213 \mathrm{mg}$ $\left.p^{-1}{ }^{-1}\right)$. A significantly higher P content was observed with the application of $S @ 30 \mathrm{~kg} \mathrm{ha}^{-1}$. This might be due to synergistic effect of S on P. Suresh (2008) reported similar result in lady's finger. The interaction effects of $P$ and $S$ was statistically significant. The highest and lowest $P$ uptakes were found in $\mathrm{P}_{60} \mathrm{~S}_{30}$ (543 mg pot $\left.{ }^{-1}\right)$ and $P_{0} S_{0}\left(117 \mathrm{mg} \mathrm{pot}^{-1}\right)$, respectively. Application of $P$ and $S$ enhanced the uptake of $P$ in plant. Thakre et al. (2005) observed similar findings in brinjal.

Potassium uptake: Uptake of $\mathrm{K}$ significantly influenced due to the application of different $\mathrm{P}$ levels. Uptake of K (317 mg pot $\left.{ }^{-1}\right)$ was obtained with application of P @ $60 \mathrm{~kg} \mathrm{ha}^{-1}$, which was significantly higher than other treatments. The lowest uptake of $\mathrm{K}$ was obtained in control $\left(112 \mathrm{mg} \mathrm{pot}^{-1}\right)$. This might be due to synergistic effect of $P$, which enhanced the uptake of $K$ nutrient by the crop. These results were in agreement with the findings of Kadu et al. (2005) in rice. Sulphur fertilization had significant influence on K uptake. The values of $250 \mathrm{mg} \mathrm{K}$ pot $^{-1}$ and $138 \mathrm{mg} \mathrm{K} \mathrm{pot}^{-1}$ were recorded in $\mathrm{S}_{30}$ level and control, respectively. This might be due to synergistic effect of S on K. Gangadhar (2004) reported that different levels of $S$ influenced the composition and uptake of $\mathrm{K}$ in lentil and maximum was recorded at $30-40 \mathrm{~kg} \mathrm{~S}$ $\mathrm{ha}^{-1}$ application. The combined application of $\mathrm{P}_{60} \mathrm{~S}_{30}\left(60 \mathrm{~kg} \mathrm{P} \mathrm{ha}^{-1} \times 30 \mathrm{~kg} \mathrm{~S}^{-1}\right)$ recorded the maximum $\mathrm{K}$ uptake (478 mg pot $\left.{ }^{-1}\right)$ and the minimum (39 mg pot $\left.{ }^{-1}\right)$ was in control. Interaction effect of $P$ and $S$ levels was significant. Similar beneficial effects of phosphorus and sulphur interaction @ $60 \mathrm{~kg} \mathrm{P} \mathrm{ha}^{-1} \times 30 \mathrm{~kg} \mathrm{~S}$ $\mathrm{ha}^{-1}$ on $\mathrm{K}$ uptake in black gram was observed (Dwived el al., 2007). 
Sulphur uptake: Stepwise increase in $\mathrm{P}$ application resulted in significant influence on the uptake of $\mathrm{S}$ by fruit portion. The application of $60 \mathrm{~kg} \mathrm{P} \mathrm{ha}^{-1}$ recorded significantly the higher $\mathrm{S}$ uptake $\left(234 \mathrm{mg} \mathrm{pot}^{-1}\right)$ compared to other $\mathrm{P}$ levels. The lowest $\mathrm{S}$ uptake of $52 \mathrm{mg} \mathrm{pot}^{-1}$ was obtained in control treatment. Nanadal et al. (2008) observed similar result in tomato. Significant differences were noticed in the uptake of $\mathrm{S}$ by fruit portion of brinjal due to different application of $\mathrm{S}$. The significantly higher $\mathrm{S}$ uptake of $161 \mathrm{mg}$ pot ${ }^{-1}$ was noticed in the $S_{30}$ treatment, which was significantly superior to other treatments. The lowest uptake of $S$ was obtained in control $\left(91 \mathrm{mg} \mathrm{pot}^{-1}\right)$, which was significantly inferior to other treatments. Significantly higher $S$ content was observed with the application of S@ $@ 30 \mathrm{~kg} \mathrm{ha}^{-1}$. This might be due to greater availability of $S$ from the soil and its subsequent translocation into the plant. Thakre et al. (2005) reported that the increasing levels of $S$ significantly increased $S$ content in brinjal fruit and maximum content was recorded with application of $40 \mathrm{~kg} \mathrm{~S} \mathrm{ha}^{-1}$. S uptake of $356 \mathrm{mg} \mathrm{pot}^{-1}$ and $21 \mathrm{mg} \mathrm{pot}^{-1}$ were obtained in the $P_{60} S_{30}$ and $P_{0} S_{0}$ respectively. Interaction effects of $P$ and $S$ was found to be statistically significant. Sharma and Singh (2003) reported similar result found in green gram.

Calcium uptake: Different levels of $\mathrm{P}$ significantly influenced the uptake of $\mathrm{Ca}$ by fruits of brinjal. Among different levels of $\mathrm{P}, \mathrm{P}_{60}$ level recorded significantly the higher uptake of $\mathrm{Ca}\left(419 \mathrm{mg} \mathrm{pot}^{-1}\right)$ compared to other treatments and control $\left(192 \mathrm{mg} \mathrm{pot}^{-1}\right)$. This might be due to synergistic effect of $\mathrm{P}$ on $\mathrm{Ca}$. This finding was similar to the result of Suresh (2008) in lady's finger. Sulphur fertilization also had significant response on $\mathrm{Ca}$ uptake. Treatment $S_{30}$ recorded significantly the higher Ca uptake (335 mg pot ${ }^{-1}$ ) over other $\mathrm{S}$ levels. This might be due to synergistic effect of S on Ca. Singh et al. (2007) found that in potato, there was a gradual increase in Ca uptake with increasing levels of $S$ upto $30 \mathrm{~kg} \mathrm{ha}^{-1}$. The highest (551 $\mathrm{mg} \mathrm{pot}{ }^{-1}$ ) and lowest (107 mg pot ${ }^{-1}$ ) uptakes of Ca were recorded in $\mathrm{P}_{60} \mathrm{~S}_{30}$ and $\mathrm{P}_{0} \mathrm{~S}_{0}$ levels, respectively. Interaction effect was found to be significant. Combination of $\mathrm{P}$ and $\mathrm{S}$ fertilizers enhanced $\mathrm{Ca}$ uptake. This was similar to the findings of Misra (2003).

Magnesium uptake: The data on uptake of $\mathrm{Mg}$ revealed that the application of $60 \mathrm{~kg} \mathrm{P} \mathrm{ha}^{-1}$ recorded significantly higher Mg uptake (354 mg pot ${ }^{-1}$ ) by fruit of brinjal over other treatments. The lowest uptake of $\mathrm{Mg}$ was noticed in control (138 mg pot ${ }^{-1}$ ). Majumdar et al. (2007) observed similar type of result. Significant differences with respect to uptake of $\mathrm{Mg}$ were observed due to application of different levels of $\mathrm{S}$. A significantly higher uptake of $\mathrm{Mg}\left(263 \mathrm{mg} \mathrm{pot}^{-1}\right)$ was observed in $\mathrm{S}_{30}$ level over $\mathrm{S}_{15}$ level (234 mg pot ${ }^{1}$ ) and control $\left(182 \mathrm{mg} \mathrm{pot}^{-1}\right)$. This might be due to synergistic effect of $\mathrm{S}$ on Mg. Gangadhar (2009) observed that the application of S increased the uptake of $\mathrm{Mg}$ by 70.2 per cent compared to control upto $30 \mathrm{~kg} \mathrm{~S} \mathrm{ha}^{-1}$ in vegetable crop like cauliflower. Interaction effects of $P$ and S showed significant difference with respect to uptake of $\mathrm{Mg}$ by brinjal fruit. The maximum (478 mg pot ${ }^{-1}$ ) and minimum $\left(70 \mathrm{mg} \mathrm{pot}^{-1}\right)$ uptakes were found in $\mathrm{P}_{60} \mathrm{~S}_{30}$ and $\mathrm{P}_{0} \mathrm{~S}_{0}$ treatments, respectively. Different levels $\mathrm{P}$ and $\mathrm{S}$ influenced the uptake of Mg. Application of P and S @ $60 \mathrm{~kg} \mathrm{ha}^{-1} \times 30 \mathrm{~kg} \mathrm{ha}^{-1}$ promoted the highest uptake of Mg. Misra (2003) reported similar result in tomato.

\section{Conclusion}

Single application of $P$ upto $60 \mathrm{~kg} \mathrm{ha}^{-1}$ and S upto $30 \mathrm{~kg} \mathrm{ha}^{-1}$ increased N, P, K, S, Ca and Mg contents in brinjal fruit. Interaction effect of $\mathrm{P} \times \mathrm{S}$ on chemical and biochemical constituents of brinjal were also significant. The overall results suggest that $\mathrm{P} @ 60 \mathrm{Kg} \mathrm{ha}^{-1}$ and $\mathrm{S} @ 30 \mathrm{Kg} \mathrm{ha}^{-1}$ along with other recommended fertilizers can be used for cultivation of better nutrient contents brinjal in the agro-climatic condition of BAU.

\section{References}

Ananthi, S., Veeragavathatham, O. and Srinivasan, K. 2004. Comparative efficacy of mutriate of phosphorus as DAP on yield attributes, yield and economics of chilli (Capsicum annuum L.). South Indian Horticulture. 52(1-6) : 158 - 163.

Badiger, M. K., Subbareddy, N. P., Roselind Michel and Shivaraj, B. 2006. Influence of phosphorus fertilizer on the yield and quality attributes of tomato. Journal of the Indian Society of Soil Science. 43: 123-129.

Balasubramanian, A.S., Kothandaraman, G.V. and Krishnamoorthy, K.K. 2005. Effect of phosphorus application on the yield and quality of mustard. Journal of the Kerala Agriculture. 19(3): 84-97.

BARC (Bangladesh Agricultural Research Council), 1997. Fertilizer Recommendation Guide. Farmgate, Dhaka. 41: 25.

Bose, S. and Som, K. 1986. Nutrients composition in vegetable crops. Indian Journal of the Agricultural Science. 59(2): 196 - 208.

Dass, R.C. and Mishra, S.N. 2002. Effect of nitrogen, phosphorus and potassium on growth, yield and quality of chilli (Capsicum annuum, L.). Journal of Plant Science. $4: 78-83$.

Dwived, G.K., Singh, V.P. and Dwived, M. 2007. Effect of phosphorus and sulphur application on the nutrient quality of different varieties/strains of black gram (Vigna mungoi L. Hepper). Indian Journal of Agricultural Chemistry. 30(1) : 21- 27. 
Gangadhar, R.M. 2009. Influence of graded levels of nitrogen, sulphur and zinc nutrition on growth, yield and essential nutrient contents of cauliflower in Red Sandy loam soils. M.Sc. (Agri.) Thesis, University of Agricultural Sciences, Bangalore.

Ghosh, A.B., Bajaj, J.C., Hasan, R. and Singh, D. 1983. Soil and Water Testing Method. A Laboratory Manual, Division of Soil Science and Agricultural Chemisiry, IARI, New Delhi, India. p. 221-226.

Gomez, K.A. and Gomez A.A. 1984. Statistical Procedure for Agricultural Research. International Rice Research Institute. The Philipines.

Hariyappa, N. 2006. Effect of phosphorus and sulphur on growth, yield and quality parameters of onion (Allium cepa L.). M. Sc. (Agri.) Thesis, University of Agricultural Sciences, Dharwad.

Hasan, M.M., Chowdhury, M.A.H., Saha, B.K. and Islam, M.R. 2013. Influence of phosphorus and sulphur on yield, yield attributes and biochemical composition of brinjal. Journal of Agroforestry and Environment. (Accepted).

Jackson, M.L. 1973. Soil Chemical Analysis. Prentice Hall of India Pvt. Ltd., New Delhi. p. 151-154.

Kadu, P.B., Bhoyar, V.S. and Thakare, R.S. 2005. Effect of NPK-FYM blended manorial mixtures on performance of rice. Journal of Soils and Crops. (2): 172-179.

Majumdar, S.D., Meena, R.L. and Baghel, G.D.S. 2007. Effect of levels of compaction and phosphorus on yield and quality of tomato and chilli crops grown on highly permeable soil. Journal of the Indian Society of Soil Science. 48(2) : $215-220$.

Misra, S.K. 2003. Effect of sulphur and potassium on yield and quality characteristics of tomato in udic haplusteps of Kanpur. Indian Journal of Soil Science. 51(4) : $544-548$.

Nanadal, J.K., Ramesh, V. and Pandey, U.P. 2008. Effect of phosphorus and potassium on growth, yield and quality of tomato. Journal of Agricultural Research. 15(1-4) : $44-49$.

Page, A.L., Miller, R.H. and Keeney, D.R. (ed) 1982. Methods of Soil Analysis, Part-2, American Society of Agronomy, Inc. Madison, Wisconsin, U.S.A. pp 152-531.

Parihar, S.S. and Tripathi, R.S. 2003. Dry matter nodulation and nutrient uptake in potato as influenced by irrigation and P. Experimental Agriculture. 25(3): 349-355.

Rachappa, B.A.S. 2004. Effect of mulches and nutrient management on growth and yield of Carrot M. Sc. (Agri) Thesis, University of Agricultural Sciences, Dharwad.

Satter, M.A. and Ahmed, S.U. 2008. Response of mungbean to inoculation with Bradyohizobium and affected by $P$ levels. Proceeding of Commission IV Conference, Bangladesh. 1-3 December, 2002. pp. 419-423.

Sharma, M.P. and Singh, R. 2003. Effect of P and S application on yield and quality of green gram (Phaseolus radialus). Indian Journal of Agricultural Science. 63(8): 507-508.

Singh, V. and Rathore, S.S. 2004. Effect of applied phosphorus and sulphur on yield, oil content and their uptake by linseed. Journal of Agricultural Research. 10(4): 407-410.

Singh, A.L., Vidya Chaudhari and Chaudhari, V. 2007. Sources of S application on potato productivity. Journal of Plant Nutrition. 18: 12.

Sivakumaran, S. 2005. Effect of levels of nitrogen, phosphorus and sulphur on yield and quality of coriander (Coriandrum sativum L.). M. Sc. (Agri.) Thesis, University of Agricultural Sciences, Bangalore.

Suresh, V.V. 2008. Effect of nitrogen, sulphur and phosphorus on yield and quality parameters of Lady's finger M. Sc. (Agri.) Thesis University of Agricultural Sciences, Dharwad.

Tabatabai, M.A. 2001. Sulphur in Agriculture. Agronomy Monograph Series No. 27. Madison, Washington, U.S.A.

Thakre, C.M., Badole, W.P., Tiwari, T.K. and Sarode, P.B. 2005. Effect of different levels of sulphur, phosphorus and potassium on yield and quality of brinjal. Journal of Maharashtra Agricultural University. 30(3) : $352-353$. 